\title{
VIEWPOINT
}

\section{An update on the declining sex ratio in India}

VIBHUTI PATEL

Reader, Centre for Women's Studies, Department of Economics, University of Mumbai. e-mail: vibhuti@vsnl.com

Indian women face covert violence before birth through sex pre-selection, and overt violence after conception through sex-selective abortion. While abortion is legal in India, sex-selective abortion is not. Amniocentesis, chorionic villus biopsy (CVB), sonography, ultrasound and imaging techniques are used to determine the sex of the foetus (1). In vitro fertilisation (IVF) clinics for assisted reproduction are approached by infertile couples to produce sons. This has resulted in a decline in the juvenile sex ratio and 60 lakh missing girls in the age group of $0-6$ years, as per the Census of India, 2001.

New reproductive technologies (NRTs) and women NRTs refer to four types of functions: IVF and subsequent embryo transfer, gamete intrafallopian transfer, zygote intra fallopian transfer, and cloning assisted reproduction. While the new contraceptive technologies are used before conception, older methods such as amniocentesis, CVB and ultrasound are used after conception.

Supporters of sex-selection tests for elimination of female foetuses have justified their views on the basis of the law of supply and demand. However, there has been a continuous decline in the sex ratio from 972 women per 1000 men in 1901 to 933 women per 1000 men in 2001. In other countries, sex ratios at birth are also skewed in favour of men.

States with widespread use of sex-selection tests Haryana has the most depressing figures-the current sex ratio in Haryana is 861 females per 1000 males, the lowest among the major states in India. According to a UNFPA study, female foeticide has been the main cause of the declining sex ratio in Haryana. A study conducted in states known for high rates of abortion-Andhra Pradesh, Bihar, Gujarat, Haryana, Madhya Pradesh, Punjab, Rajasthan, Tamil Nadu and Uttar Pradeshrevealed the impact of sex-selective abortion in widening the gender gap. Interestingly, Punjab and Haryana are two of the most economically prosperous states in India.
Table 1 Sex ratio among the states with widespread use of sex determination tests

$\begin{array}{lll}\text { State } & \mathbf{1 9 9 1} & \mathbf{2 0 0 1} \\ \text { Punjab } & \mathbf{8 7 5} & 793 \\ \text { Haryana } & 879 & 820 \\ \text { Gujarat } & 928 & 878 \\ \text { Maharashtra } & 946 & 917\end{array}$

Source: Census of India, 2001.

\section{Initiatives taken by the State and NGOs:}

In response to a public interest petition, the Supreme Court of India gave a directive on May 4, 2001 to all state governments to implement the Prenatal Diagnostics Techniques (Regulation and Prevention of Misuse) Act promptly and effectively (enacted in 1994 and brought into operation from January 1, 1996). According to this directive, all bodies under the PNDT Act, namely genetic counselling centres, genetic laboratories and genetic clinics, cannot function unless registered (2). The Prenatal Diagnostic Techniques (Prohibition of Sex Selection) Act, 2003 specifically prohibits the use of new technology for the purpose of sex selection (4). The Municipal Corporation of Mumbai has initiated a drive against unauthorised determination of the sex of the foetus. All sonography centres are required to register themselves with the appropriate authority and must display a message that under no circumstances will the sex of the foetus be disclosed. The Indian Medical Association and the Federation of Obstetrics and Gynaecological Societies of India too have condemned sex-selective abortions and abuse of NRTs for sex selection.

We have to change the mindset of doctors and their clients and create a sociocultural milieu that is conducive for survival of the girl child. Then only will we be able to halt the declining sex ratio.

\section{References}

1. Patel V. Girl child: an endangered species? In: Kripal $\mathrm{V}(\mathrm{ed})$. The girl child in 20th century Indian literature. New Delhi: Sterling Publications, 1992;9.

2. Handbook on PNDT Act, 1994. Department of Family Welfare, Government of India, New Delhi, 2002.

3. Kamdar S. Sex selection law tightened. The Times of India June 6, 2003. 